\title{
Two new species of social wasps (Hymenoptera, Vespidae) from Roraima, Northern Brazil ${ }^{1}$
}

Anthony Raw ${ }^{2,3}$

\begin{abstract}
The females and nests are described of two new species of social wasps (Hymenoptera, Vespidae) from dry evergreen forest on the Ilha de Maracá, Roraima, Brazil. Mischocyttarus (Monocyttarus) maracaensis sp.n. closely resembles $M$. flavicornis Zikán, 1935 in morphology and coloration. Polybia (Myrapetra) roraimae sp.n. is a member of the $P$. occidentalis (Olivier, 1791) group of species.

KEY WORDS. Hymenoptera, Vespidae, Mischocyttarus, Polybia, Amazônia, Brazil, systematics
\end{abstract}

During ecological studies on social wasps on the Ilha de Maracá, in Roraima, northern Brazil I collected two previously unknown species which are described below. The Ilha de Maracá lies $205 \mathrm{~km} \mathrm{SSW}$ of Mount Roraima which is the junction of Brazil with Guyana and Venezuela, and $100 \mathrm{~km}$ WNW of Boa Vista.

\section{Mischocyttarus (Monocyttarus) maracaensis sp.n.}

Mischocyttarus (Monocyttarus) maracaensis Raw, 1992: 510; nom. nud. (ICZN, Art. 1le - without description). - Raw, 1998: 317; nom. nud. (ICZN, Art. 11e - without description).

Holotype female. Length of body $14 \mathrm{~mm}$. Length of fore wing $12 \mathrm{~mm}$. Body golden yellow with black and brown dorsal markings. Black areas are a patch enclosing ocelli with arm extending half way towards each antennal socket, occipital band narrowly linked to ocellar area and with an arm extending to top of each orbit; three mesoscutal stripes joined narrowly in front and behind; part of mesoscutum bordering each tegula yellow. Dark brown areas are dorsal stripe on the antennal scape, humeral stripe, narrow anterior margin and central line of scutellum, narrow central line of propodeum and most of second to fifth metasomal tergites except the apical margin and sides which are yellow. Mid brown areas are a central spot in front of the pronotal keel, apical half of first metasomal tergite except the apical margin (which is yellow), stripe on upper side of hind coxa and apical segment of hind tarsus. Orange-brown areas are flagellum of antenna, apical margin of clypeus and mandibular teeth. The wings are hyaline with red-brown venation.

Clypeus wider than high (6: 5), simply angled below and its sides touching eye for $2 \mathrm{x}$ the diameter of an antennal socket. Lateral ocelli separated by one ocellar diameter. Genal carina lacking. Width of gena at its mid point $2 \mathrm{x}$ width of eye. Malar space $<1 / 2$ width of antennal socket. Frons densely punctured on its upper

1) Work financed by the Royal Geographical Society of London.

2) Departamento de Zoologia, Universidade de Brasília. 70910-900 Brasília, Distrito Federal, Brasil.

3) Present address: Departamento de Ciências Biológicas, Universidade Estadual de Santa Cruz. 45650-000 Ilhéus, Bahia, Brasil. 
$2 / 3$. Lower $1 / 3$ of clypeus and mandible sparsely punctured and granulate. Mandible quadridentate. Pronotal keel straight in lateral view and sharp throughout its length; a little higher centrally, lobed laterally and ending abruptly. Front margin of pronotum raised and lamellate; furrow behind it distinct and with hind margin raised acutely. Pronotal fovea present and with short distinct carina in front of it. Dorsal groove of mesepisternum, scrobe and scrobal furrow present. Mesepisternum, metanotum and propodeum granulate. Mesoscutum and scutellum very densely and finely punctured. Central furrow of propodeum long, wide, quite shallow and lacking a central keel. Opening of muscle slit arched; valves of propodeum very low and transparent. Third tarsal segment of mid and hind legs moderately and fourth strongly asymmetrical. Larger claw of hind leg thickened and rather blunt. First metasomal tergite gradually expanded posteriorly, its hind margin $2.5 \mathrm{x}$ width of the base, and the apical width $2.8 \mathrm{x}$ its length (measured from the posterior side of ligamentary aperture). The male is not known.

Type locality. Edge of dry evergreen forest, $4 \mathrm{~km}$ from the eastern end of the Ilha de Maracá, and $1 \mathrm{~km}$ north of the Maracá branch of the river Uraricoera, Roraima, Brazil ( $3^{\circ} 38^{\prime} \mathrm{N}$ and $\left.61^{\circ} 51^{\prime} \mathrm{W}\right)$.

Type material. The holotype is deposited in the collection of the Instituto Nacional de Pesquisas Amazônicas (INPA), Manaus. Paratype females are deposited in the collections of the author, the Museu de Zoologia, Universidade de São Paulo; Smithsonian Institution, Washington DC and the Oxford University Museum.

Mischocyttarus maracaensis sp.n. closely resembles M. flavicornis Zikán, 1935, differing from it in the following characters. In M. flavicornis the clypeus touches the eye for $1.5 \mathrm{x}$ the width of an antennal socket, the lateral ocelli are separated by $1.3 \mathrm{x}$ an ocellar diameter, the lateral lobes of the pronotal keel are lower, the propodeal furrow lacks a keel, the first metasomal tergite is wider $(2.0 \mathrm{x}$ its length), the second to fifth metasomal tergites are mid brown, and there are more dark integumental markings. The mesepisternal sutures and much of the sides of the propodeum are dark brown. M. maracaensis sp.n. also resembles $M$. flavicornis nigricornis Zikán, 1949 in having the antenna and the posterior half of the metanotum dark brown.

One nest of M. maracaensis sp.n. was $1.7 \mathrm{~m}$ from the ground, attached to the underside of a leaf of a sapling at the edge of a clearing. It comprised 19 cells. They were $3 \mathrm{~mm}$ wide, three were $8 \mathrm{~mm}$ to $15 \mathrm{~mm}$ long and contained larvae and 16 were $2 \mathrm{~mm}$ to $8 \mathrm{~mm}$ long and contained eggs. Two adult females were present on the nest.

\section{Polybia (Myrapetra) roraimae sp.n.}

Polybia occidentalis ssp.: Raw, 1992: 510.

Polybia roraimae Raw, 1998: 320; nom. nud. (ICZN, Art. 11e - without description).

Holotype female. Length of body $7.3 \mathrm{~mm}$. Length of fore wing $5.8 \mathrm{~mm}$. Body black with yellow markings. The following parts are bright lemon yellow: pronotal band ( $1 / 2$ width of second flagellar segment along centre and $2 \mathrm{X}$ width of 
second flagellar segment along sides, scutellum and metanotum (except posterior margins), two large patches on propodeum (except anterior sides and propodeal furrow), mesopleural patch in front of scrobal furrow, posterior margins of first to fifth tergites and second to fifth sternites, part of first tergite enclosed by lateral keels. Lower and lateral margins of clypeus dull yellow. Antenna, legs and venation of wings dark brown.

Occipital margin clearly indicated by a line along occiput and gena to $1 / 2$ way down length of orbit. Upper part of gena wider than lower part, almost as wide as adjacent part of orbit. Pronotal keel indicated; slightly angled. Scrobal furrow complete. Entrance to spiracular chamber of mesopleuron very low. White appressed tomentum on propodeum, sides of thorax and coxae. Ratio of length: maximum width of first metasomal tergite as 1:1.54. Erect bristles on lower margin of clypeus. Few erect bristles on coxae, tarsi, propodeum, first and second sternites and sixth tergite.

The male is not known.

Type locality. Dry evergreen forest, $4 \mathrm{~km}$ from the eastern end of the Ilha de Maracá, and $2 \mathrm{~km}$ north of the Maracá branch of the river Uraricoera, Roraima, Brazil ( $3^{\circ} 38^{\prime} \mathrm{N}$ and $\left.61^{\circ} 51^{\prime} \mathrm{W}\right)$.

Type material. The holotype is deposited in the collection of the Instituto Nacional de Pesquisas Amazônicas (INPA), Manaus. Paratype females are deposited in the collections of the author, the Smithsonian Institution, Washington DC; American Museum of Natural History, New York; the Oxford University Museum and the Museu Paraense Emílio Goeldi, Belém.

Polybia roraimae sp.n. is a member of the $P$. occidentalis (Olivier, 1791) group and it runs to P. scutellaris (White, 1841) in RICHARDs' key (1978: 41, couplet 34) of southern Brazil and Argentina; a larger species whose large nest is very distinctive. Polybia roraimae sp.n. is the smallest known member of the $P$. occidentalis group. The fore wing $(5.8 \mathrm{~mm}$ long $)$ is shorter than that of $P$. juruana von Ihering, 1904, the next smallest species whose fore wing measures $6.7 \mathrm{~mm}$. It also differs from the others of the group in possessing a moderately well defined pronotal keel and in the entrance to spiracular chamber of the mesopleuron which is even lower than that of $P$. scutellaris. The first metasomal tergite is narrower than that of the sympatric $P$. occidentalis venezuelana Soika, 1965. The ratio of length: width of the two are, respectively 1:1.54 and 1:1.91. However, it resembles $P$. belemensis Richards, 1970 and P. platycephala Richards, 1951 in its narrow gena and P. juruana and P. scrobalis Richards, 1970 in bearing a complete scrobal furrow.

The nest is like that of closely related species. Two nests collected each contained three combs. One nest was $30 \mathrm{~cm}$ high and $70 \mathrm{~cm}$ diameter and the second was $30 \mathrm{~cm}$ high and $60 \mathrm{~cm}$ diameter. The envelope of both was mottled mid brown and fragile. The mature cells were $8 \mathrm{~mm}$ or $9 \mathrm{~mm}$ long and $2.5 \mathrm{~mm}$ wide. The cap of the cocoon was white and hemispherical and extended up to $2 \mathrm{~mm}$ beyond the rim of the cell. 
ACKNOWLEDGEMENTS. The work was part of the Maracá Project 1987-88 (Secretaria Especial para o Meio Ambiente de Brasília, Royal Geographical Society of London and Instituto Nacional de Pesquisas de Amazônia, Manaus). I thank these institutions for their support. My special thanks are to Dr. Gillian Thompson, University of Stirling, who discovered the nests of several species of wasps and showed me the first nest of P. roraimae sp.n..

\section{REFERENCES}

ICZN (International Commission on Zoological Nomenclature). 1985. International Code of Zoological Nomenclature. London, British Museum (Natural History), $3^{\text {rd }}$ ed., $338 \mathrm{p}$.

RAW, A. 1992. The forest: savanna margin and habitat selection by Brazilian social wasps (Hymenoptera: Vespidae), p.499-511. In: P.A. FURLEY; J.A. RATTER \& J. PROCTOR (Eds). The Nature and Dynamics of the Forest-Savanna Boundary. Chapman and Hall, 616p.

1998. Social wasps (Hymenoptera, Vespidae) of the Ilha de Maracá, p. 307-321. In: J.A. RATTER \& W. MILLIKEN (Eds). Maracá: The Biodiversity and Environment of an Amazonian Rainforest. Chichester, John Wiley \& Sons, 508p.

RicharDS, O.W. 1978. The Social Wasps of the Americas. London, British Museum (Natural History), 580p.

Recebido em 26.V.1999; aceito em 14.IX.1999. 